\title{
Geology of the Shelves surrounding the New Siberian Islands, Russian Arctic
}

\author{
D. Franke and K. Hinz \\ Federal Institute for Geosciences and Natural Resources (BGR), P.O. Box 510153, 30631 Hannover, Germany
}

\begin{abstract}
A total of $11700 \mathrm{~km}$ of multichannel seismic reflection data were acquired during recent reconnaissance surveys of the wide, shallow shelves of the Laptev and western East Siberian Seas around the New Siberian Islands. To the north of the Laptev Sea, the Gakkel Ridge, an active mid-ocean ridge which separates the North American and Eurasian Plates, meets abruptly the steep slope of the continental shelf. Extension has affected the Laptev Shelf since at least the Early Tertiary and has resulted in the formation of three major, generally north-south trending rift basins: the Ust' Lena Rift, the Anisin Basin, and the New Siberian Basin. Our data indicate that the rift basins on the Laptev Shelf are not continuous with those on the East Siberian Shelf. The latter shelf can best be described as an epicontinental platform which has undergone continuous subsidence since the Late Cretaceous. The greatest subsidence occurred in the NE, manifested by a major depocentre filled with inferred (?)Late Cretaceous to Tertiary sediments up to $5 \mathrm{~s}$ (twt) thick. On the basis of deep reflection data we revise and adjust Mesozoic domain boundaries around the New Siberian Islands.
\end{abstract}

\section{Introduction}

The vast and semi-permanent ice covered shelves around the New Siberian Islands are a unique region for studying the spatial and temporal variation and mechanics of lithospheric extension. The active spreading centre in the Arctic Ocean, the Gakkel Ridge, which also represents the plate boundary between the North America and Eurasia Plates, is the slowest spreading segment of the global mid-ocean ridge system. Total spreading rates range from $12.7 \mathrm{~mm} / \mathrm{a}$ near Greenland to $6 \mathrm{~mm} / \mathrm{a}$ in the Eurasia Basin, where the ridge meets the adjacent continental margin of the Laptev Sea abruptly at a

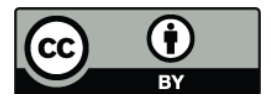

Correspondence to: D. Franke (dieter.franke@bgr.de) curvilinear slope. On the adjacent continental shelf spreading is accommodated by continental rifting resulting in the formation of a huge rift system, the Laptev Sea Rift (Franke et al., 2001).

The Federal Institute for Geosciences and Natural Resources (BGR), in co-operation with Sevmorneftegeofizika (SMNG), carried out three seismic cruises on the shelves around the New Siberian Islands: in 1993 a grid of multichannel seismic reflection lines (total $3189 \mathrm{~km}$ ) was surveyed on the outer shelves of the Laptev and New Siberian Seas north of the New Siberian Islands (Roeser et al., 1995; Franke and Hinz, 2005). In 1994 seismic reconnaissance data (total $3965 \mathrm{~km}$ ) have been acquired primarily in the western Siberian Sea south of latitude $76^{\circ} \mathrm{N}$ (Franke et al., 2004), and in 1997 about $4623 \mathrm{~km}$ of MCS data were collected in the eastern Laptev Sea (Franke et al., 2001) with some additional lines in the East Siberian Sea and the western Laptev Sea. In this contribution we summarize the results of the three surveys.

\section{Geological setting}

The accretion of several terranes to the paleo-Siberian continental margins in the Late Paleozoic and Mesozoic resulted in the formation of several large fold belts: the New Siberian fold belt, which includes the New Siberian Islands and surrounding Laptev Sea-East Siberian Sea continental shelves, the Taimyr, Verkhoyansk and Cherskii fold belts (e.g. Fujita and Newberry, 1982; Zonenshain et al., 1990; Parfenov, 1991; Fujita et al., 1997; Khain, 1994; Drachev et al., 1998; Fig. 1). The Chukchi fold belt, which includes the mainland, Wrangel Island, and associated Chukchi Sea shelf lies east of the study area.

The fold belts underwent intensive pervasive deformation and were intruded by granitic plutons during Middle Jurassic to Lower Cretaceous time. Following this regional deformation the formation of large extensional basins has been postulated, which are named Blagoveshenk, New Siberian, North Chukchi/Vil'kitskii (e.g. Kos'ko, 1984; Grantz et al., 1990),

Published by Copernicus Publications on behalf of the European Geosciences Union. 


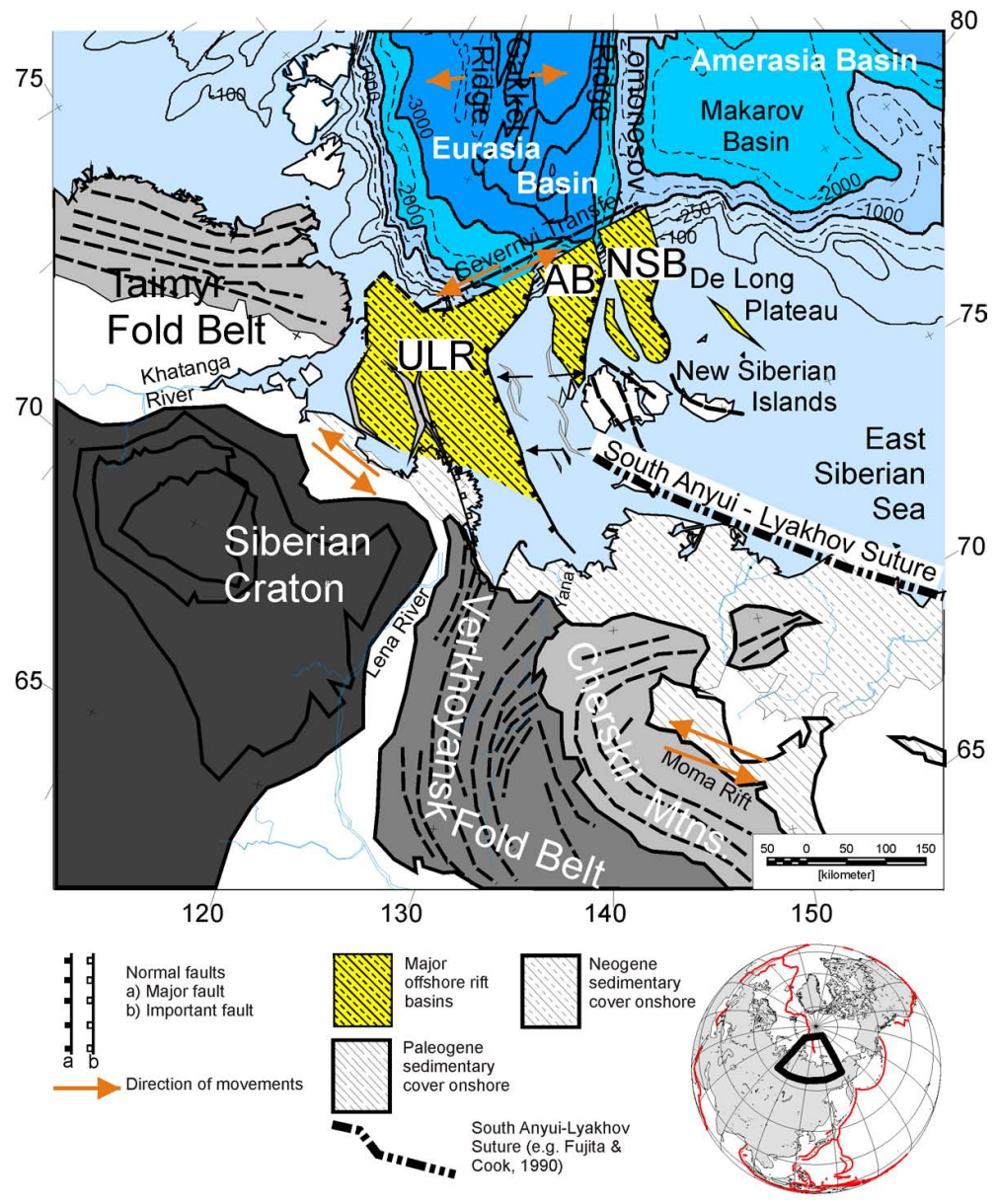

Fig. 1. Main structural elements in the study area in polar-stereographic projection. URL denotes the Ust' Lena Rift, AB the Anisin Basin, NSB the New Siberian Basin. The onshore structures were modified from the geological map (Nalivkin, 1983).

and which are believed to be filled primarily with Paleozoic to Mesozoic - and possible some Cenozoic - sediments. Knowledge of the kinematics and history of the pre-Tertiary opening of the Arctic Ocean Basin is still insufficient, despite the numerous models for the origin of the Amerasia Basin: A popular western model involves the opening of the Amerasia Basin by in-situ seafloor spreading and counterclockwise rotation of the Arctic Alaska-Chukchi-Ancestral Plate away from Arctic Canada about a pivot point situated in northern Yukon, whereas a popular model in the former Soviet Union involves the formation of the Amerasia Basin by lithospheric oceanization and granitization. Lawver and Scotese (1990) discuss a variety of proposed models for the origin of the Amerasia Basin falling under the following categories: entrapment of older oceanic crust, in-situ seafloor spreading and rotation, movement of continental blocks by strike-slip and associated spreading.

The Cenozoic development of the Arctic Ocean Basin is better constrained: there is general consensus that the opening of the Eurasia Basin initiated with the splitting of the North America-Eurasia lithospheric plates during the Late
Cretaceous, and that at the time of magnetic anomaly \#24/25 (52.4-55.9 Ma, according to Cande and Kent, 1995) the Eurasia Basin opened along the Gakkel Ridge (e.g. Srivastava and Tapscott, 1986; Rowley and Lottes, 1988; Kristoffersen, 1990; Jackson and Gunnarson, 1990). It is assumed that the creation of rift basins on the Laptev Sea shelf began at the same time (e.g. Grachev, 1983; Fujita and Cook, 1990; Drachev et al., 1998; Franke et al., 2000, 2001). From extrapolation of onshore geology the shelves of the Laptev Sea and East Siberian Sea are subdivided into the following four domains (e.g. Fujita and Cook, 1990; Kos'ko and Trufanov, 2002; cf. Fig. 2) from the west to the east:

Kotel'nyi Domain comprises Kotel'nyi and the small Bel'kov Islands. It is characterized by a nearly continuous succession of thick Paleozoic carbonates and pelitic to sandy deposits of Mesozoic to Cenozoic age. The Paleozoic and Mesozoic deposits are folded in northwest-striking anticlines and synclines (Vol'nov et al., 1970). Truncation, peneplanation, and weathering at the transition from Mesozoic to Tertiary deposits are widespread. 


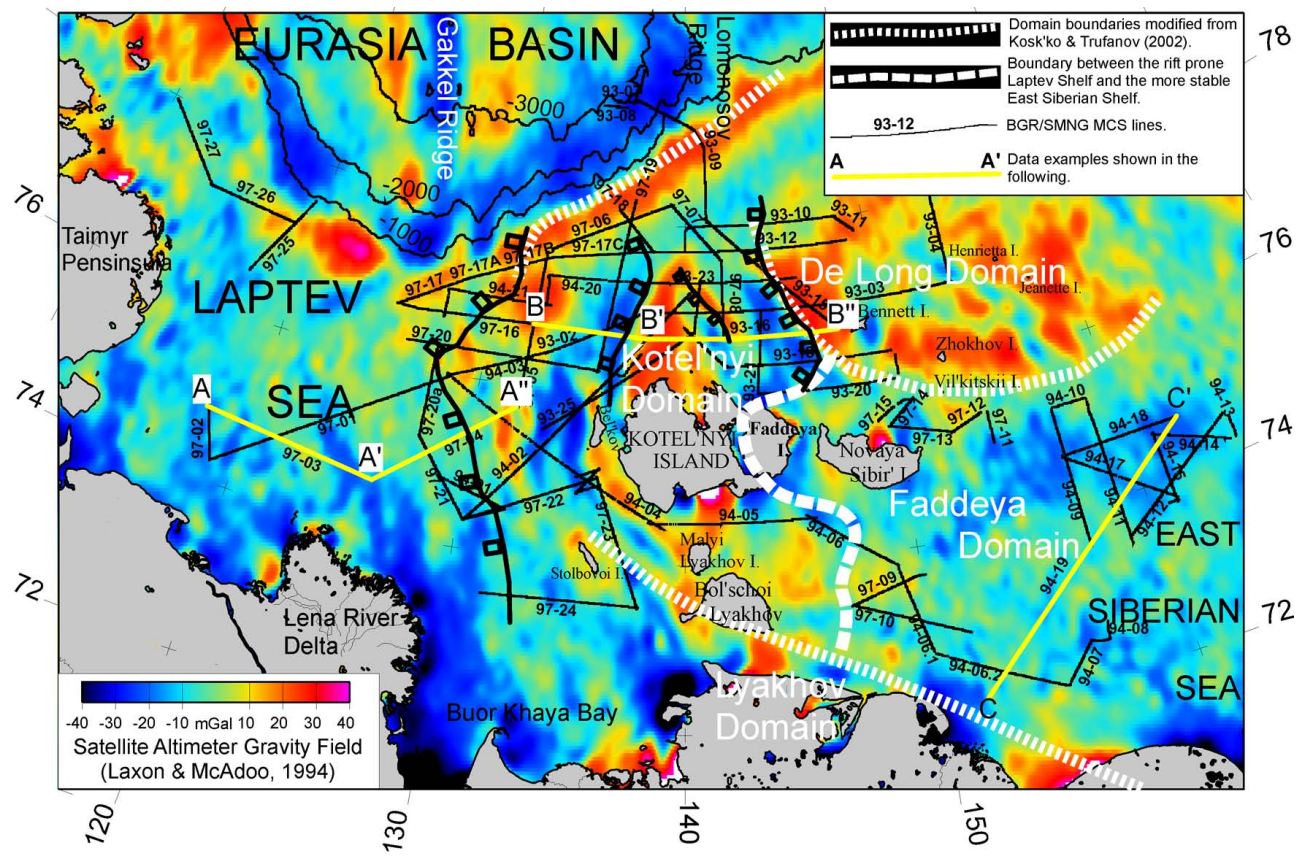

Fig. 2. Altimeter derived gravity field (Laxon and McAdoo, 1994) and location of the reflection seismic lines acquired by BGR in cooperation with SMNG. The extensions of the different domains in the area were modified from Kos'ko and Trufanov (2002). The locations of the interpreted seismic line-drawings shown in Figs. 4 and 5 are indicated in yellow.

Lyakhov Domain comprises the Lyakhov Islands and Stolbovoi Island including the South Anyui suture. It is characterized by thrusted sequences of Late Paleozoic ophiolites, Permian to Triassic clastic turbidites, Upper Jurassic to Lower Cretaceous basaltic rocks, and intruded granites and granodiorites (Fujita and Newberry, 1982; Fujita and Cook, 1990; Drachev and Savostin, 1993; Drachev et al., 1998).

Faddeya Domain, also called Novaya Sibir'Terrane by Fujita and Cook (1990), comprises the islands of Novaya Sibir' and Faddeya, and probably underlies a large portion of the East Siberian Shelf (Fujita and Cook, 1990). It is characterized by extensive Paleogene coal-bearing terrigenous formations, and it is separated from the Kotel'nyi Domain by a fault zone located between Kotel'nyi and Faddeya Islands. The oldest exposed rocks forming the Novosibirsk complex of Late Cretaceous to Eocene age are extensively deformed into folds. The Faddeya Domain is thought to represent a region of early Paleogene subsidence, which underwent deformation in Late Oligocene time (Fujita and Cook, 1990).

De Long Domain encompasses Bennett, Henrietta, Jeanette, Zhokov and Vil'kitkii Islands (Fig. 2). Moderately tilted Cambrian to Ordovician siliclastic rocks crop out on Bennett Islands, and Paleozoic igneous rocks, volcaniclastics and siliclastics deposits are known from Henrietta Island (Vinogradov, 1984). Paleozoic basic lavas, volcaniclastics and siliclastics have been reported from Henrietta Island (e.g. Kos'ko and Trufanov, 2002) and Aptian basaltic magmatism affected Bennett Island (Drachev and Saunders, 2006).

\section{Seismic images and seismic stratigraphy of the acous- tic basement and the superimposed layered succession}

Since no deep wells have been drilled on the shelves surrounding the New Siberian Islands, the proposed age and nature of the defined major seismic horizons have still some uncertainties.

\subsection{Laptev Sea Shelf}

By extrapolation from known major unconformities and hiatuses on the New Siberian Islands (Kos'ko et al., 1990; Kos'ko and Trufanov, 2002), from the onshore area of Buor Khaya Bay (Drachev et al., 1998), and correlating regional seismic unconformities to major plate tectonic events, as well as to major paleoenviromental changes observed in the northern oceans, three regional seismic marker horizons labeled LS1 (Laptev Sea 1), LS2 and LS3 have been defined, albeit some more but less distinct and less continuous seismic horizons are present. Horizon LS1 is the most prominent and extensive horizon. It is a distinct erosional unconformity that appears as a peneplain on several structural highs, and it forms the base of the sedimentary infill of the rift basins. It developed prior to the major Cenozoic stretching episode following regional uplift and subsequent strong erosion and weathering during Late Cretaceous (?) and Early Paleocene time in the Laptev Sea area (Kim, 1986; Patyk-Kara and Laukhin, 1986). We assign an age between $65 \mathrm{Ma}$ and $56 \mathrm{Ma}$ 
to horizon LS1, because this interval represents several important tectonic episodes in the Arctic. Among these are: Initiation of seafloor spreading in the Eurasia Basin (Jackson and Gunnarson, 1990; Kristoffersen, 1990), separation of Greenland from Eurasia during chron 24R (e.g. Eldholm et al., 1989), and final separation of Greenland from North America in the Paleocene (Chalmers et al., 1993).

Unconformity LS2 marks the top of a highly reflective sequence which is absent on the most elevated horsts. An Early Oligocene age (about $33 \mathrm{Ma}$ ) was assigned to horizon LS2, because of the documentation of an erosional event in the beginning of the Oligocene at several localities on the New Siberian Islands (Kos'ko and Trufanov, 2002), and a major global sea-level fall near the Rupelian/Chattian boundary (Haq et al., 1988).

Unconformity LS3 is manifested in the seismic data by a distinct change in the reflection pattern, from pronounced sub-parallel bedding to a less reflective sequence. LS3 probably represents a drastic change in the depositional regime during the Neogene. We assign a Late Miocene age (between 5-10 Ma) to horizon LS3, because of a revival of tectonic activity in the Verkhoyansk-Chukchi region at about the end of the Miocene (e.g. Khain, 1994), the initiation of large-scale northern hemispheric glaciation (e.g. Myhre and Thiede, 1995; Mangerud et al., 1996).

\subsection{East Siberian Sea shelf}

The seismic reconnaissance lines show a well layered succession representing sediments, and resting on a smooth acoustic basement mostly lacking a coherent internal reflection pattern. Horizon ESS1 (East Siberian Sea 1), manifested as the base of the layered succession in the seismic data, forms the surface of the acoustic basement and most probably represents the peneplained surface of the complex PaleozoicMesozoic New Siberian-Chukchi fold belt. It must be stated that the stratigraphy of the East Siberian Shelf is even less well constrained with respect to the Laptev Sea because a well dated event, notably the initial opening of the Eurasia Basin is missing in that region. Albeit the entire sedimentary succession, or parts of it, may be of Cretaceous age, we tentatively infer a Late Cretaceous age for horizon ESS1. This is based on a period of leveling evidenced by the formation of extensive surfaces of planation, as well as weathering horizons and thin coal-bearing limnic sediments which followed the Late Cretaceous halt of granitoid plutonism in the Verkhoyansk-Chukotka folded system (Parfenov, 1991; Drachev et al., 1998). The layered succession is subdivided by at least two distinct regional seismic marker horizons, labeled ESS2 and ESS3, which show some common reflection characteristics to the seismic marker horizons LS2 and LS3 from the Laptev Shelf, discussed before. If the assumption of a Late Cretaceous age is correct for horizon ESS1 the horizons ESS2 and ESS3 might have similar ages as LS2 and LS3, i.e. Early Oligocene and Late Miocene, respectively.

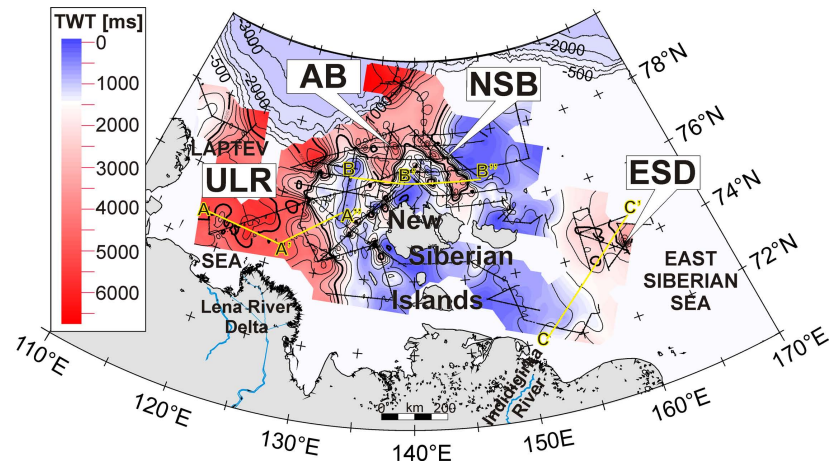

Fig. 3. Sedimentary thickness map of the Laptev Rift system. Shown is the gridded depth to the acoustic basement (marker horizon LS1/ESS1) in milliseconds (twt). Contours are shown every $500 \mathrm{~ms}$ with thick lines at $2500 \mathrm{~ms}$ and $5000 \mathrm{~ms}$ (twt). The locations of the line-drawing interpretations shown in Figs. 4 and 5 are indicated in yellow. ULR denotes the Ust' Lena Rift, AB the Anisin Basin, NSB the New Siberian Basin, and ESD the East Siberian Depocenter.

However, it might well be that horizon ESS2 corresponds to horizon LS1 from the Laptev Shelf. In that case the major parts of the sedimentary successions on the East Siberian Shelf would be of Cretaceous age.

\section{Major rift features of the Laptev Shelf}

The major rift basins on the Laptev Shelf are the Ust' Lena Rift, the Anisin Basin, and the New Siberian Basin (Fig. 2). Figure 3 shows the depth of the primarily Cenozoic sedimentary cover to the acoustic basement (LS1 and ESS1, respectively) on the Laptev and East Siberian shelves in milliseconds (two-way traveltime, twt). Some line drawing interpretations of MCS profiles from the Laptev Shelf have been prepared for the following discussion of the major rift features. Lines BGR97-03 and BGR97-04 (Fig. 4, lower panel and Fig. 5) traverse the Ust'Lena Rift and the Laptev Horst in a west-northwest-east-southeast and southwest-northeast direction, respectively. Lines BGR97-16 and BGR93-16 (Fig. 4, upper panel and Fig. 6) run across the Anisin Basin, the Kotel'nyi Horst, the Neben Basin, and the New Siberian Basin in a west-east direction. The Bel'khov Svyatoi Nos Rift is a narrow half-graben west of Kotel'nyi Island with a maximum depth of $5 \mathrm{~km}$ and a width of less than $25 \mathrm{~km}$ (e.g. Drachev et al., 1998; Franke et al., 2001). This half-graben trends NW-SE across the Laptev Horst and belongs to the category of smaller basins that developed in the horst region. 


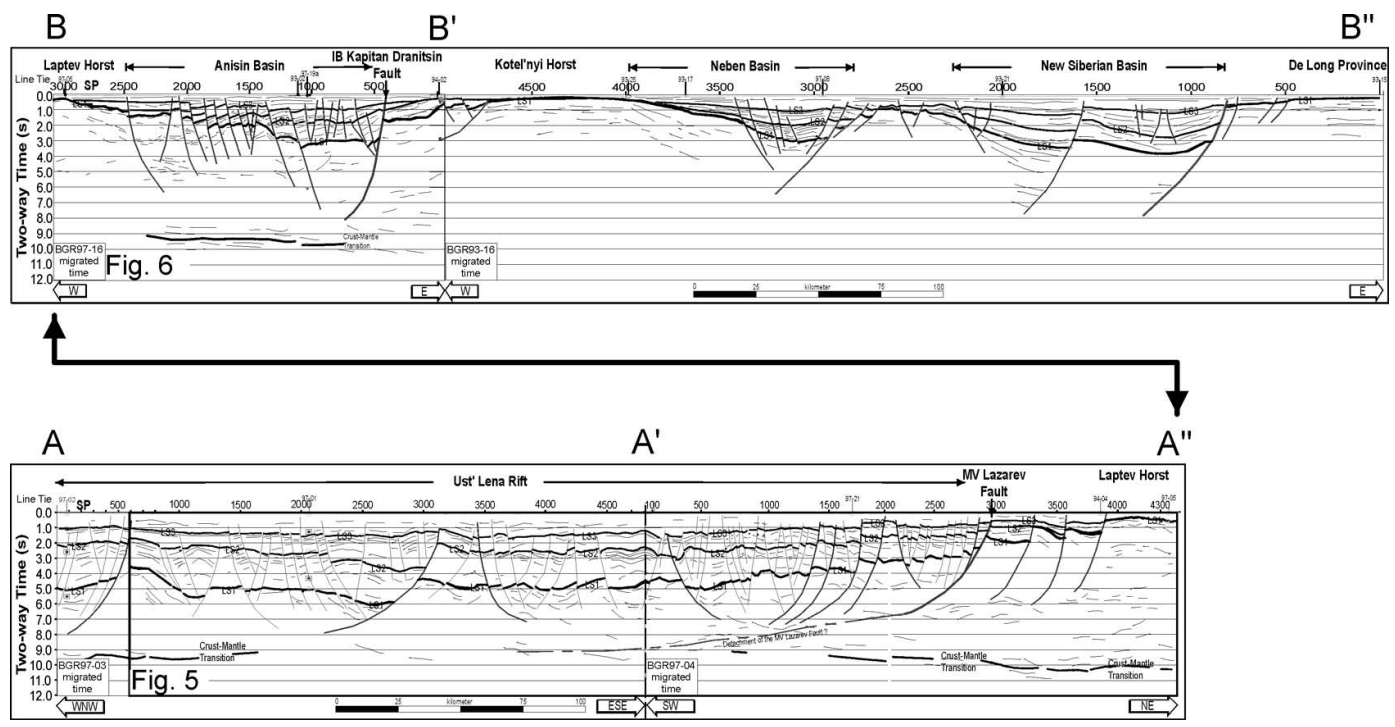

Fig. 4. Line drawing interpretation of MCS lines BGR97-03/-04 (lower panel) across the Ust'Lena Rift and eastern part of BGR97-16 and BGR93-16 (upper panel) across the Anisin, the Neben, and the New Siberian Basins. LS1, LS2 and LS3 denote the individual marker horizons. For location see Figs. 2 and 3.
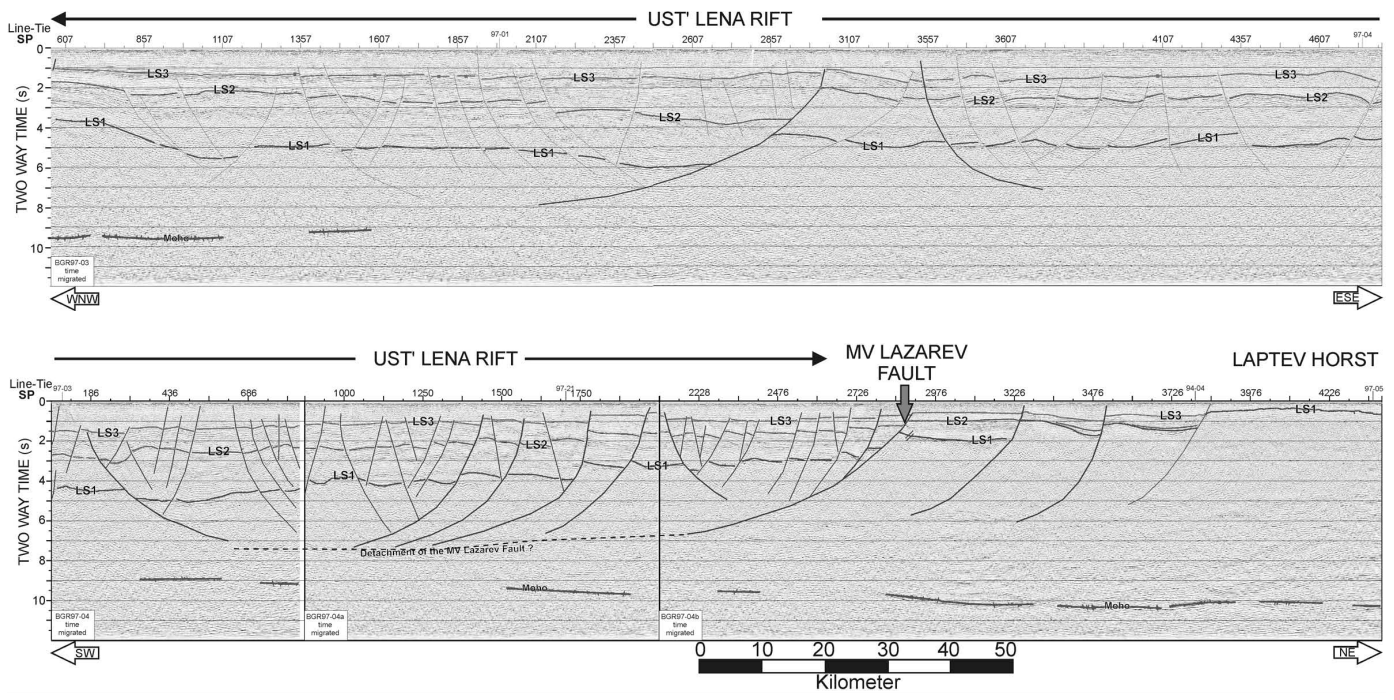

Fig. 5. Time migrated sections of the eastern part of line BGR97-03 (top) and lines BGR97-04, -04a, -04b (bottom) across the eastern Ust'Lena Rift onto the Laptev Horst. LS1, LS2 and LS3 denote the individual marker horizons. For location see Figs. 2 and 4.

\section{Ust'Lena Rift}

The Ust'Lena Rift, with a minimum width of $380 \mathrm{~km}$, covers the main part of the Laptev Shelf. Its western flank is not covered by our data set. Line BGR97-03 (Fig. 4, lower panel) starts in the area of the defined South Laptev Basin (e.g. Drachev et al., 1995) and runs with a general $98^{\circ}$ orientation across the Ust'Lena Rift. Horizon LS1, interpreted to represent the rift-onset unconformity forms the base of the sedimentary infill with thicknesses in the range between 4 and $5.5 \mathrm{~s}(\mathrm{twt})$. The major portion of the sedimentary infill is of Paleogene age suggesting that the development of the Ust'Lena Rift was nearly completed prior to the forming of unconformity LS3. Line BGR97-04 continues Line BGR97-03 to the east in a north $47^{\circ}$ east direction (Fig. 4, lower panel). The Cenozoic sedimentary basin fill thins continuously from $5 \mathrm{~s}(\mathrm{twt})$ in the eastern part of the basin to $2.5 \mathrm{~s}$ (twt) at the MV Lazarev Fault (Fig. 3). This distinct westerly dipping listric fault bounds the Ust'Lena Rift in the east against the Laptev Horst. The MV Lazarev Fault 

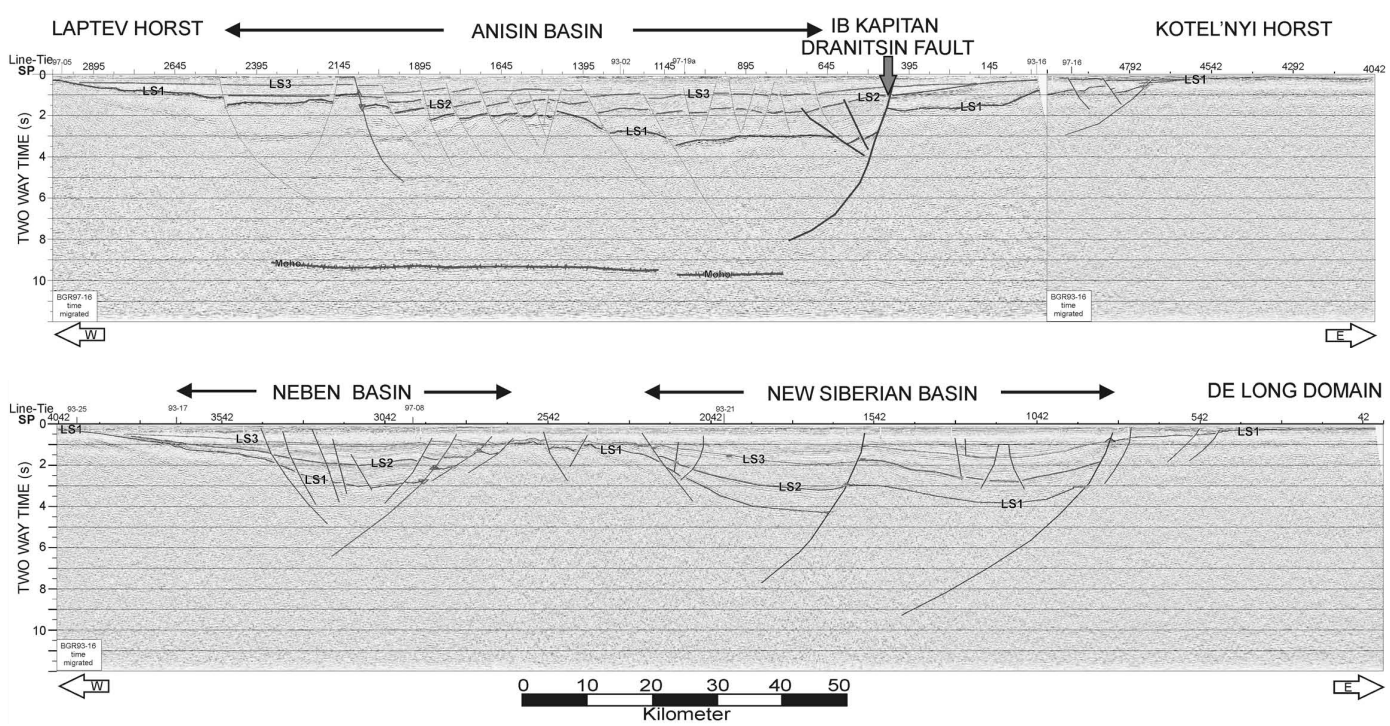

Fig. 6. Time migrated sections of the eastern part of line BGR97-16 (top) and line BGR93-16 (bottom) across the Laptev Horst, the southern part of the Anisin Basin, the Kotel'nyi Horst, the Neben Basin, the New Siberian Basin, and the De Long Domain. LS1, LS2 and LS3 denote the individual marker horizons. For location see Figs. 2 and 4.

penetrates the whole upper crust and flattens down at the top of a reflective lower crustal unit at a level of approximately 7-8 s (twt). A high reflective crustal unit between 7 and $9 \mathrm{~s}$ (twt) extends westward from the MV Lazarev Fault for some $100 \mathrm{~km}$ toward the rift centre (Fig. 4, lower panel). Several listric faults penetrate most of the upper crust down to the band of sub-horizontal reflections. This zone of high crustal reflectivity thins to the west and merges finally down to the interpreted crust-mantle boundary (MOHO). Beyond and west of this point (Line BGR97-03) the middle and lower crust shows no coherent reflection elements. We interpret the high-reflective band as the detachment plane of the MV Lazarev Fault (cf. Figs. 4 and 5). A band of high reflectivity at crustal levels between 8 and $9 \mathrm{~s}$ (twt), locally present along lines BGR97-03 and -04 is thought to image the crust-mantle transition.

\section{Anisin Basin}

This rift basin extends along longitude $136^{\circ} \mathrm{E}$ from latitudes $76^{\circ} \mathrm{N}$ to $78^{\circ} \mathrm{N}$. It is about $40 \mathrm{~km}$ wide at the southern end but broadens to about $150 \mathrm{~km}$ at latitude $78^{\circ} \mathrm{N}$ (Fig. 4, upper panel; see also Fig. 3). The basin is imaged in the satellite altimeter gravity map as a gravity low (Fig. 2). The eastern part of Line BGR97-16 (Fig. 4, upper panel and Fig. 6) traverses from the Laptev Horst in the west across the Anisin Basin. A prominent north-northeast to southsouthwest trending listric fault, the IB Kapitan Dranitsin Fault, bounds the basin against the Kotel'nyi Horst in the east. The acoustic basement dips to the east within the basin
(Fig. 4, upper panel and Fig. 6) resulting in an increase of the thickness of the primarily Cenozoic basin fill from about $1.5 \mathrm{~s}(\mathrm{twt})$ at the western flank to $3.5 \mathrm{~s}(\mathrm{twt})$ at shotpoint 480 near the eastern flank. However, the thickness of the basin infill increases gradually towards the north to about $5 \mathrm{~s} \mathrm{(twt)}$ (Fig. 3). There is some evidence that extension affected the western half of the Anisin Basin during the Neogene resulting in basement partitioning associated with the formation of small-offset faults which penetrate unconformity LS3.

\section{New Siberian Basin and Neben Basin}

Line BGR93-16 (Fig. 4, upper panel and Fig. 6, lower panel) traverses from the Kotel'nyi Horst in the west across the Neben Basin and the New Siberian Basin onto the De Long Plateau in the east. Both northwest trending basins, the about $35 \mathrm{~km}$ wide Neben Basin and the $40 \mathrm{~km}$ to $75 \mathrm{~km}$ wide New Siberian Basin, are best described as half grabens, bounded at their eastern side by a deep reaching listric fault. Depressed and faulted basement blocks form the base of the sedimentary infill which is subdivided by unconformities LS2 and LS3 into three depositional units. The sedimentary basin infill of the New Siberian Basin, increasing in thickness from the southern end of the basin to the north, has a maximum thickness of more than $4.5 \mathrm{~s}$ (twt). Our data show unequivocally that the New Siberian Basin disappears as a conclusive rift basin when approaching Faddeya and Novaya Sibir' Islands (Fig. 3). 


\section{Structural features and dominant tectonic style of the East Siberian Shelf}

The De Long Plateau, located between about $75.5^{\circ} \mathrm{N}$ and $78.5^{\circ} \mathrm{N}, 145^{\circ} \mathrm{E}$ and $157^{\circ} \mathrm{E}$, covers a large area of the East Siberian Shelf (Fig. 1). It is well imaged in compilations of potential field data (MacNab, 1993; Verhoef et al., 1996; Laxon and McAdoo, 1994; Drachev et al., 1999; Piskarev et al., 2001; Fig. 2). Basaltic effusives overlie Paleozoic rocks. Though the age of the volcanic flow units, each $40-100 \mathrm{~m}$ thick (Kos'ko and Trufanov, 2002) is still debated most authors agree that they were emplaced in Cretaceous times in a subaerial environment (e.g. Kos'ko, 1984; Fujita and Cook, 1990; Sekretov, 2002; Kos'ko and Trufanov, 2002; Drachev and Saunders, 2006). However, there is also evidence for Pliocene and Quaternary volcanism from K-Ar rock age determination of basalts from Zhokov and Vil'kitskii Islands (Vinogradov, 1977; Kos'ko and Trufanov, 2002). Only one narrow, less than $10 \mathrm{~km}$ wide, graben with a maximum sedimentary infill of only $1 \mathrm{~s}(\mathrm{twt})$ was recognized in our seismic data from the De Long region, whereas termination of the seismic marker horizons against the sea floor by onlap is manifested in the seismic data at several localities, indicating uplift and associated intensive erosion of the De Long region since at least the Late Miocene.

A sedimentary depocenter to the southeast of the De Long Domain is well imaged as a gravity low in Fig. 2. It is filled with more than $4 \mathrm{~s}(\mathrm{twt})$ sediments resting on top of marker horizon ESS1 (Fig. 3). Line BGR94-19 (Figs. 7 and 8) has been chosen to show the structural style of that part of the East Siberian Shelf that is located to the south of the De Long Plateau. The line runs north-northeast from Indigirka Bay in the south up to latitude $75^{\circ} \mathrm{N}$. The well-layered sedimentary unit superimposed on the surface of the acoustic basement, labeled ESS1, thickens from about $1 \mathrm{~s}(\mathrm{twt})$ in the south to more than $4 \mathrm{~s}(\mathrm{twt})$ in the north near the southern front of the De Long Plateau.

Along the southern half of the line the surface of the acoustic basement dips gently towards the north, but along the northern half of the line, i.e. between shotpoints 1 to 4250 , several listric faults displace the surface of the acoustic basement and the older sedimentary unit resting on horizon ESS1 and bounded by unconformity ESS2. Horizon ESS3, tentatively interpreted as the base of the (?)Late Miocene through Quaternary cover, is rarely affected by this faulting. It appears that the entire region traversed by the line is controlled mainly by subsidence. Although Franke et al. (2004) described the presence of some narrow sag basins, trending west-northwest, which developed after the formation of unconformity ESS2 but definitively prior to the formation of ESS3, they categorize the East Siberian Shelf surveyed by them as an epicontinental platform that gradually subsided and was filled up by sediments since the Late Cretaceous.

\section{Discussion and conclusions}

From the interpretation of our seismic data we conclude that the described rift basins of the Laptev Shelf were primarily formed in interaction with the opening of the Eurasia Basin. This view is only partly shared by Drachev et al. (1998), who relates the opening of the New Siberian Basin to the opening of the Makarov Basin, a sub-basin of the Amerasia Basin, in Late Cretaceous (80-53 MA). There is convincing evidence from geophysical data that the rift basins of the Laptev Shelf terminate to the north against a major northeast to southwest trending tectonic boundary defined by Fujita et al. (1990) as Severnyi Transfer (Fig. 1), also named Northern Fracture by Drachev et al. (1998, 1999). This lineament may explain the linkage between the opening by seafloor spreading of the Eurasia Basin and extension of the Laptev Shelf. Opening of the Eurasia Basin by seafloor spreading was accommodated by preferential thinning of the continental crust on the Laptev Shelf. The fact that the north-northwest to south-southeast trending rifted basins of the Laptev Shelf coincide with the general trend of the South Anyui suture suggest that these basins formed along a zone of weakness that presumably was created in association with the subduction of the proto-Anyui Ocean.

Though, conclusive definition of Mesozoic domain boundaries on the basis of deep reflection data alone is difficult, because not only different lithologies but also a combination of ductile stretching and magmatic additions to the crust can create high reflectivity in the deeper crust in extensional settings (e.g. McCarthy and Thompson, 1988), we have tentatively extended the proposed boundaries of the Kotel'nyi Domain (e.g. Kos'ko and Trufanov, 2002) to the offshore areas (Fig. 2). We have done this because on several lines close to Kotel'nyi Island there is a high-reflective reflection band imaged in the upper crustal level beneath marker horizon LS1. The estimated velocity of about $4.6 \mathrm{~km} / \mathrm{s}$ for a layer corresponding to the band (Franke et al., 2001) suggests that it represents the base of the 6-10 km thick Paleozoic to Mesozoic carbonates known from the New Siberian Islands (Kos'ko and Trufanov, 2002). Due to the distinct difference concerning size and architecture between the Anisin, Neben, and New Siberian Basins, which are best described as half-grabens, and the Ust'Lena Rift, we propose an additional major tectonic boundary close to the location of the MV Lazarev Fault. If the South Anyui suture extends to the Laptev Sea this tectonic boundary might have been formed by the further extent of that suture onto the Laptev Shelf and/or a major global-scale transform. The latter is proposed within the popular hypothesis of a counter-clockwise rotational opening of the Amerasia Basin (Grantz et al., 1990) to trend along the eastern base of the Lomonosov Ridge and to meet the South Anyui suture somewhere around the New Siberian Islands. 


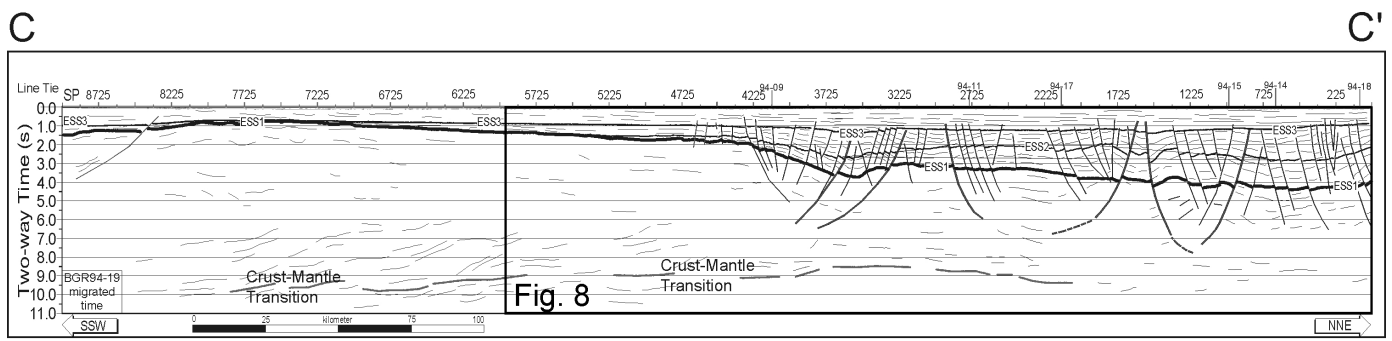

Fig. 7. Line drawing interpretation of MCS lines BGR94-19 across the East Siberian Shelf. ESS1, ESS2 and ESS3 denote the individual marker horizons. For location see Figs. 2 and 3.

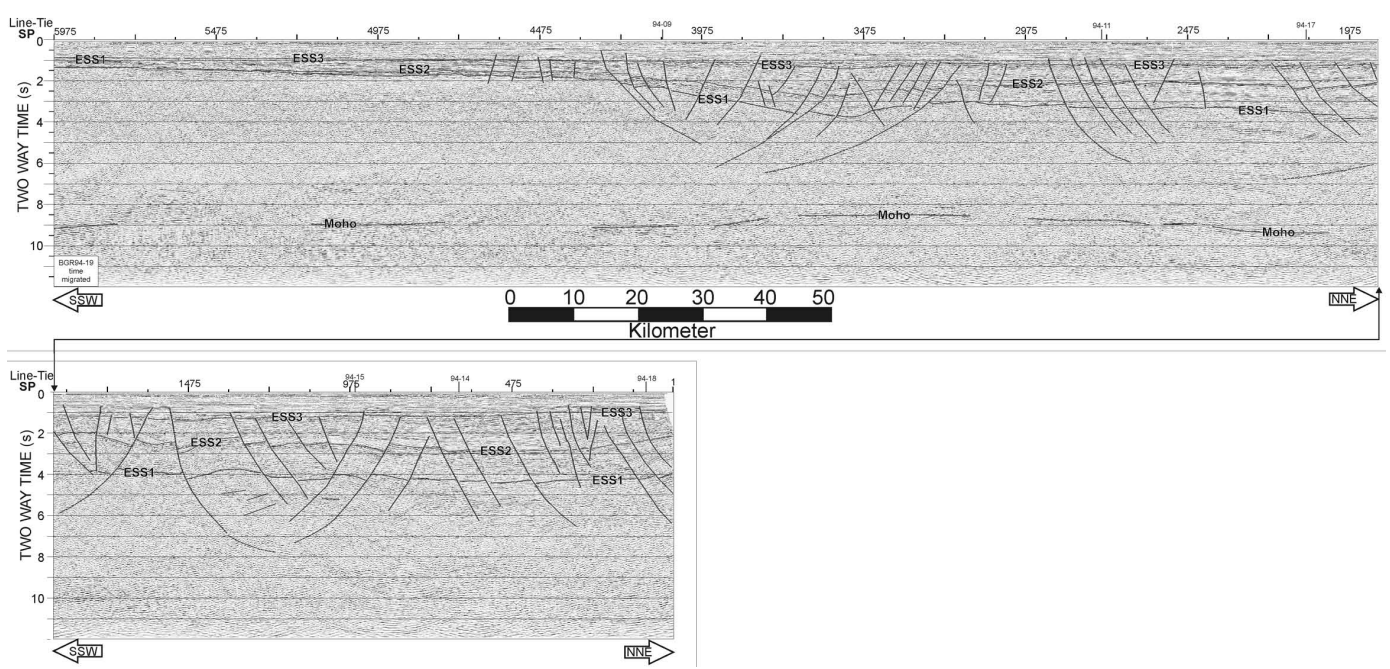

Fig. 8. Time migrated section of the eastern part of line BGR94-19 across the East Siberian Shelf. ESS1, ESS2 and ESS3 denote the individual marker horizons (see text). For location see Figs. 2 and 7.

Adding the width of all the major rift basins of the Laptev Shelf in east-west direction we get a value of about $580 \mathrm{~km}$ extension since the Paleocene. This value is close to a model of Gaina et al. (2002), who studied the deformation along the Laptev Sea's plate boundary on the basis of magnetic and gravity data. In the Laptev Sea, at $72^{\circ} \mathrm{N}$ and $122^{\circ} \mathrm{E}$, their model predicts extension and transtension in the range of $452 \mathrm{~km} \pm 20 \mathrm{~km}$ from $68.7 \mathrm{Ma}$ to the Middle Eocene, and extension in the range of $186 \mathrm{~km} \pm 28 \mathrm{~km}$ until the present. An episode of transpression from the Oligocene to the Middle Miocene as suggested by Drachev et al. (1998) is predicted by the Gaina et al. (2002) model only for the southern part of the Laptev Shelf with $9 \mathrm{~km} \pm 3 \mathrm{~km}$ at $69^{\circ} \mathrm{N}$ and $130^{\circ} \mathrm{E}$ for the Early to Middle Miocene. We found only negligible evidence for compression in our data.

Our seismic data from the East Siberia Shelf (Franke et al., 2004; Franke and Hinz, 2005) allow the statement that large late Lower Cretaceous-Tertiary rift basins of the tectonic style of both the Ust' Lena Rift and the Anisin, Neben and New Siberian Basins, do not exist on the surveyed part of the East Siberia Shelf. The East Siberia Shelf can be considered as a relative stable epicontinental platform, composed of a complex suite of Paleozoic and Mesozoic rocks that subsided and sediments were deposited gradually since Late Cretaceous or earlier (?) time with stronger subsidence toward the north.

Acknowledgements. Funding of the seismic surveys and this work was provided by the Federal Institute for Geosciences and Natural Resources (BGR), Hannover; Germany. Reviews and suggestions by B. Coakley and W. Jokat and D. Stone are kindly acknowledged.

\section{References}

Cande, S. C. and Kent, D. V.: Revised calibration of the geomagnetic polarity timescale for the late Cretaceous and Cenozoic, J. Geophys. Res., 100, 6093-6095, 1995.

Chalmers, J. A., Pulvertaft, T. C. R., Christiansen, F. G., Larsen, H. C., Laursen, K. H., and Ottesen, T. G.: The southern West Greenland continental margin: rifting history, basin development, and 
petroleum potential, in: Petroleum Geology of Northwest Europe: Proc. of the 4th Conference, edited by: Parker, J. R., Geological Society Publication, London, 915-931, 1993.

Drachev, S. S. and Savostin, L. A.: Ophiolites of the Bol'shoi Lyakhov Island (Novosibirsk Islands), Geotektonika, 6, 33-51, 1993.

Drachev, S. S., Savostin, L. A., and Bruni, I. E.: Structural pattern and tectonic history of the Laptev Sea Region, edited by: Kassens, H., Piepenburg, D., Thiede, J., Reports on Polar Research, 176, 348-366, 1995.

Drachev, S. S., Savostin, L. A., Groshev, V. G., and Bruni, I. E.: Structure and Geology of the continental shelf of the Laptev Sea, Eastern Russian Arctic, Tectonophysics, 298, 357-393, 1998.

Drachev, S. S., Johnson, G. L., Laxon, S. W., McAdoo, D. C., and Kassens, H.: Main structural elements of Eastern Russian Arctic continental margin derived from satellite gravity and multichannel seismic reflection data, in: Land-Ocean Systems in the Siberian Arctic: Dynamics and History, edited by: H. Kassens, H., Bauch, H. A., Dimitrenko, I. A., et al., Springer, 667-692, 1999.

Drachev, S. S. and Saunders, A.: The early Cretaceous Arctic LIP: Its geodynamic setting and implications for Canada Basin opening, in: Proceedings of the Fourth International Conference on Arctic Margins, edited by: Scott, R. A. and Thurston, D. K., OCS Study MMS 2006-003, 216-223, 2006.

Eldholm, O., Thiede, J., Taylor, E., et al.: Evolution of the Vøring Volcanic Margin, in: Proceedings of the Ocean Drilling Program, College Station, TX (Ocean Drilling Programme), Scientific Results, 104, 1989.

Franke, D., Hinz, K., Block, M., Drachev, S. S., Neben, S., Kos'ko, M. K., Reichert, C., and Roeser, H. A.: Tectonics of the Laptev Sea region in north-eastern Siberia, in: ICAM III: III. International Conference on Arctic Margins, edited by: Roland, N. W. and Tessensohn, F., published by the Alfred-Wegener-Institute for Polar and Marine Research and the German Society of Polar Research Bremerhaven, Polarforschung, 68(1998), 51-58, 2000.

Franke, D., Hinz, K., and Oncken, O.: The Laptev Sea Rift, Mar. Petrol. Geol., 18(10), 1083-1127, 2001.

Franke, D., Hinz, K., and Reichert, C.: Geology of the Shelf of the East Siberian Sea south of the De Long Uplift/Russian Arctic from seismic images, J. Geophys. Res., 109(B7), B07106, 10.1029/2003JB002687, 2004.

Franke, D. and Hinz, K.: The structural style of sedimentary basins on the shelves of the Laptev Sea and the western East Siberian Sea, Siberian Arctic, J. Petrol. Geol., 28(3), 269-286, 2005.

Fujita, K. and Newberry, J. T.: Tectonic evolution of Northeastern Siberia and adjacent regions, Tectonophysics, 89, 337-357, 1982.

Fujita, K. and Cook, D. B.: The Arctic continental margin of eastern Siberia, in: The Geology of North America, Vol. L, The Arctic Ocean Region, edited by: Grantz, A., Johnson, L., and Sweeney, J. F., Geol. Soc. Am., 289-304, 1990.

Fujita, K., Cambray, F. W., and Velbel, M. A.: Tectonics of the Laptev Sea and Moma Rift Systems, Northeastern USSR, Mar. Geol., 93, 95-118, 1990.

Fujita, K., Stone, D. B., Layer, P. W., Parfenov, L. M., and Koz'min, B. M.: Cooperative programme help decipher tectonics of Northeastern Russia, EOS T. Am. Geophys. Un., 78, 245, 252-253, 1997.
Gaina, C., Roest, W. R., and Müller, R. D.: Late CretaceousCenozoic deformation of northeast Asia, Earth Planet. Sc. Lett., 197, 273-286, 2002.

Grachev, A. F.: Geodynamics of the transitional zone from the Moma Rift to the Gakkel Ridge, in: Studies in Continental Margin Geology, edited by: Watkins, J. S. and Drake, C. L., American Association of Petroleum Geologists, Memoirs, 34, 103113, 1983.

Grantz, A., May, S. D., and Hart, P. E.: Geology of the Arctic continental margin of Alaska, in: The Geology of North America, Vol. L, edited by: Grantz, A., Johnson, L., and Sweeney, J. F., The Arctic Ocean Region, Geological Society of America, Boulder, Colorado, 257-288, 1990.

Haq, B. U., Hardenbrol, J., and Vail, P. R.: Mesozoic and Cenozoic Chronostratigraphy and Cycles of sea-level change. Sea-Level Changes - An Integrated Approach, SEPM Special Publication, 42, 71-108, 1988.

Jackson, H. R. and Gunnarsson, K.: Reconstructions of the Arctic: Mesozoic to Present, Tectonophysics, 172, 303-322, 1990.

Khain, V. E.: Geology of Northern Eurasia (Ex USSR), 2. Phanerozoic fold belts and young platforms, Bornträger, Berlin, ISSN 3443-11024-X, 404 pp., 1994.

Kim, B. I.: Cenozoic history of the development of the East Arctic shelves and paleoshelves, in: Structure and history of development of the Arctic ocean, edited by: Egiazarov, B. Kh. and Kazmin, Y. B., Sevmorgeologiya, Leningrad, 105-119, 1986 (in Russian).

Kos'ko, M. K.: East Siberian Sea, in: Geologic Structure of USSR and its Relationship to the Distribution of Mineral Resources, Vol. 9, Seas of the Soviet Arctic, Gramberg, I. S. and Pogrebitsky, Y. E., Nedra, Leningrad, 51-60, 1984.

Kos'ko, M. K., Lopatin, B. G., and Ganelin, V. G.: Major geological features of the islands of the East Siberian and Chukchi Seas and the northern coast of Chukotka, Mar. Geol., 93, 349-367, 1990.

Kos'ko, M. K. and Trufanov, G. V.: Middle Cretaceous to Eopleistocene sequences on the New Siberian Islands: an approach to interpret offshore seismic, Mar. Petrol. Geol., 19, 901-919, 2002.

Kristoffersen, Y.: Eurasia Basin, in: The Arctic Ocean Region, The Geology of North America, Vol. L, edited by: Grantz, A., Johnson, L., and Sweeney, J. F., Geological Society of America, Boulder, Colorado, 365-378, 1990.

Lawver, L. A. and Scotese, C. R.: A review of tectonic models for the evolution of the Canada Basin, in: The Arctic Ocean Region, The Geology of North America, Vol. L, edited by: Grantz, A., Johnson, L., and Sweeney, J. F., Geological Society of America, Boulder, Colorado, 593-618, 1990.

Laxon, S. and McAdoo, D.: Arctic ocean gravity field derived from ERS-1 satellite altimetry, Science, 165, 621-624, 1994.

McCarthy, J. and Thompson, G. A.: Seismic image of extended crust with emphasis on the western United States, Geological Society of America, Bulletin, 100, 1361-1374, 1988.

McNab, R.: Russia and the Arctic Ocean, Magnetic Field and Tectonic Structures, Provisional diagram based on preliminary data and interpretations, Atlantic Geosciences Centre, chart, 1993.

Mangerud, J., Jansen, E., and Landvik, J. Y.: Late Cenozoic history of the Scandinavian and Barents ice sheets, Global Planet. Change, 12, 11-26, 1996.

Myhre, A. M. and Thiede, J.: North Atlantic - Arctic gateways, in: Proceedings of the ODP, Initial Reports, 151, edited by: Myhre, 
A. M., Thiede, J., Firth, J. V., et al., College Station, TX (Ocean Drilling Programme), 1995.

Nalivkin, D. V. (Ed.): Geological map of the USSR: Moscow, Ministry of Geology of the USSR, 16 sheets, scale 1:2 500 000, 1983.

Parfenov, L. M.: Tectonics of the Verkhoyansk-Kolyma Mesozoides in context of plate tectonics, Tectonophysics, 199, 319342, 1991.

Patyk-Kara, N. G. and Laukhin, S. A.: Cenozoic evolution of the Arctic coastal relief of North-Eastern Asia, Soviet Geology, 1, 75-84, 1986 (in Russian).

Piskarev, A. L., Roeser, H. A., Hinz, K., and Kos'ko, M. K.: Potential field studies on the crustal structure of the Laptev Sea and the western East Siberian Sea, in: ICAM III: III. International Conference on Arctic Margins. Published by the Alfred-WegenerInstitute for Polar and Marine Research and the German Society of Polar Research Bremerhaven, edited by: Roland, N. W. and Tessensohn, F., Polarforschung, ISSN 0032-2490, 69(1999), 41-50, 2001.

Roeser, H. A., Block, M., Hinz, K., and Reichert, C.: Marine geophysical investigations in the Laptev Sea and the western part of the East Siberian Sea, Reports on Polar Research (176): RussianGerman Cooperation in the Siberian Shelf Seas: Geo-System Laptev Sea, Bremerhaven, Alfred Wegener Institute for Polar and Marine Research, Germany, 367-377, 1995.

Rowley, D. B. and Lottes, A. L.: Plate-kinematic reconstructions of the North Atlantic and Arctic: Late Jurassic to Present, Tectonophysics, 155, 73-120, 1988.
Sekretov, S. B.: Structure and tectonic evolution of the Southern Eurasia Basin, Arctic Ocean, Tectonophysics, 351, 193-243, 2002.

Srivastava, S. P. and Tapscott, C.: Plate kinematics of the North Atlantic, in: The Geology of North America, Vol. M, The Western Atlantic Region. (A Decade of North American Geology), edited by: Tucholke, B. E. and Vogt, P. R., Geological Society of America, Boulder, Colorado, 379-404, 1986.

Verhoef, J., Walter, R. R., Macnab, R., Arkani-Hamed, J., and members of the project team: Magnetic anomalies of the Arctic and North Atlantic oceans and adjacent land areas, Geological Survey of Canada, Open File 3125a, 1996.

Vinogradov, V. A., Gaponenko, G. I., Gramberg, I. S., and Shimarayev, V. N.: Structural-associational complexes of the Arctic shelf of eastern Siberia, Int. Geol. Rev., 19, 1331-1343, 1977.

Vinogradov, V. A.: Laptev Sea, in: Geologic Structure of the USSR and its Relationship to the Distribution of Mineral Resources, Vol. 9, Seas of the Soviet Arctic, edited by: Gramberg, I. S. and Pogrebitskii, Y. E., Nedra, Leningrad, 51-60, 1984 (in Russian).

Vol'nov, D. A., Voitsekhovsky, V. N., Ivanov, O. A., Sorokov, D. S., and Yashin, D. S.: Novosibirskie ostrova, in: Geology SSSR, Vol. 26, Ostrova Arktiki, edited by: Tkachenko, B. V. and Egiazarov, B. K., Nedra, Moskva, 224-274, 1970.

Zonenshain, L. P., Kuz'min, M. I., and Natapov, L. M.: Geology of the USSR: A Plate-Tectonic Synthesis, in: Geodynamics Series, Vol. 21, edited by: Page, B. M., American Geophysical Union, Washington, DC, 242 pp., 1990. 